\title{
Construction of Gender through Fashion and Dressing
}

\author{
Zoi Arvanitidou \\ PhD Candidate in Folklore \\ University of the Aegean, Rhodes, Greece \\ arvanitidou@aegean.gr \\ Maria Gasouka \\ Professor Assistant of Folklore and Gender \\ University of the Aegean, Rhodes, Greece \\ mgasouka@rhodes.aegean.gr
}

\section{Doi:10.5901/mjss.2013.v4n11p111}

\section{Abstract}

During the last two centuries, the definitions of gender were bounded by increasingly blurred lines, expressing the cultural uncertainty surrounding masculinity and feminity. Besides it is known that gender is a social construction (and not only determined by biological sex). Two basics social - cultural factors that shape the gender are dressing and fashion. A chorography (especially the last two centuries) shows these different constructions of masculinity and femininity. The battle for the use of trousers by women (from Coco Channel and stars of Hollywood Greta Garbo, Marlene Dietrich and Katharine Hepburn play a significant role) confirm the different treatment of male and female. Fashion, which in essence is the fantasy of escape from the typical role of individuals, guiding and shaping the male and female roles, with the major fashion designers to play the key role in shaping it. Dress movements such as Macaroni (1760 - 1780), Baeu, (early 18th century), Dandies (early 19 th century) and Mods (20th century) and various teen subcultures show differentiation trends of certain groups. Unisex style has tried to conceal gender differences showing a masquerade of equality for all (with the hippies and Ravers to have the basic role). On the contrary androgynous style seeks to unite the male and the female body, leading to a return to a primordial cosmic unity that will appease the gender confusion and anxiety. But eventually style and androgynous Unisex highlight the differences between the sexes.

Keywords: Gender, Dress, Fashion, Masculinity, Femininity

\section{Introduction}

In the last two centuries, the definitions of gender are becoming more and more vague, reflecting the cultural uncertainty that surrounds the male and female roles. These roles provide to each the gender identity which is a social construct not only determined by biological sex.

The stereotypical masculine or feminine qualifications are not personality characteristics of individual men and women but socially constructed representations of gender, on the basis of what society expects of each sex (Condor, 1987; Lloyd \& Duveen, 1993). These expectations organize the social gender identity, making a strong frame of reference within which boys and girls socialize and adults are redefined. Thus the term gender identity refers to the construction of this identity due to the interaction with the social environment but also due to the realization of a person that it exists as a man or a woman (Cox \& Dittmar, 1995).

Because there are significant cross-cultural differences regarding the relationship of sex and clothing, this study is limited to gender dressing differences in Western societies. Also, clothing is the main instrument of the appearance of the body considering in the general sense that it includes anything that contributes to this configuration, like shoes, hairstyle, accessories and even cosmetics. Two major socio-cultural factors shaping gender are the dress and fashion.

\subsection{Dressing and Fashion}

The dress has the most direct contact with the human body and is therefore considered an integral part of the Self. Garments influence and shape the appearance with significant impact on the construction of social identity (Tseelon, 
1989). That, delegates to others and to the Self information about the economic and social situation of the wearer, occupation and nationality, but also individual properties and values (Holman, 1981; Lurie, 1981). In the dressing there are types of coded cultural identities and people interact with them through the garments (Davis, 1988).

Fashion meets people's lives and infuses them. Some follow it more or less and some not. However, daily selection of dressing affects the way they are perceived by others, defines the expectations of those around them and has the main contribution in forming impressions. In most cases the dress makes the man or woman. The costume, someone wears at work, at a social gathering or in an interview affects the perception and the opinion created on the capabilities and preferences (Giles \& William, 1975). The subjective influence of clothing, except from psychological, has also historical roots, as people choose color, style and form of garments, according to the traditional social status, role and age. All these are also influenced by the interaction with other cultures and neo-colonial or not, state of their society (Bahl, 2005).

In some societies, a particular form of dress may be used as a social control mechanism, such as political uses of women's clothing and as a means to change social norms (Bahl, 2005). The dress is among products with strong symbolism and great semantic value through the types of brands, origin, etc. (Mayer \& Belk, 1985). Mostly, it is an external signal emitting meanings of an image of the Self to others, but can also be internal, enhancing the self-image and confidence of someone to play a role (Solomon \& Douglas, 1987). The interpretation of that image is a social phenomenon because the isolated individual body image always influenced by the collective body image and the interpretation of this affect the responsive behavior (DeLong, Salusso-Deonier \& Larntz, 1983). The clothing is a form of nonverbal communication, clear enough for the user, although others interpretations may vary (Barnard, 1996).

Fashion is a social product and includes a duality: a) providing for safety and uniformity, b) for personalization. So, the person wishes to be recognized as part of a team and as a personality (Dodd at all, 1998). Where the expression of personality is undesirable, like in the army or in some companies, this is expressed through dressing, with an obligatory uniform or the khaki in the first case, or a certain suit and tie (Hughes, 2004). When someone is casually trying to decide about everyday wear, that person is influenced by historical - social factors and does not consciously think about whom she/he is or how she/he wants to be seen. The deep-seated inhibitions of Judeo-Christian tradition are expressed with modesty, prudence, lack of confidence, which are well engraved in the symbolic code of dress that prevails in the West (Davis, 1989).

\section{History}

Roles of men and women have influenced clothing and garment and vice versa. The female dress has historically limited the social roles of women both physically and symbolically. In the 19th century, the dress of non-working woman, demonstrates the economic situation of her husband, who was the supplier of the family (DeLong, Salusso-Deonier \& Larntz, 1983).

\subsection{Construction of Masculinity}

Fashion was not always gender scarred. Until the 18th century there were no significant differences in the dressing of both sexes and both men and women wore long decorated costumes. The aristocrats and bourgeois superiors, used to show the abundant lace, rich velvets, silks, decorated shoes, elaborate hats, wigs and plenty of perfume (Davis, 1992). A pink, silk suit with gold and silver decoration was seen as entirely masculine. The dress was the signifier of social class and the more elaborate it was the higher the social class. Fashion became feminized in the 19th century, when the expression of sexual difference through the clothing was more important than that of the social order (Steele, 1989). At the same time there was also a marked change in the expression of male identity through clothing. At the end of 19th century bourgeois men refrained from using all forms of decoration, gayer colorful fabrics and jewelry, leaving it all to women (Kawamura, 2005).

It's the great male abandonment, the most important event in the history of dressing, according to Flügel (1930), in which men are no longer interested in "beautiful" appearances and want it only to be useful. The systematic variations between male and female clothing began in late Middle Ages, when men's clothing appeared and reached its maximum in 1850 (Flügel, 1930). Since then, western fashion seeks to apply technical femininity in women's clothing to show their feminine qualities and this phenomenon became almost universal. The feminization of fashion started with the fall of the aristocracy and the rise of the bourgeoisie and was accelerated by the French Revolution. Then the Protestant values of thrift, hard work and individual economic progress dominated and these values reflect on men's clothing (Davis, 1992). 
While men competed hard in the arena of politics and business, they gave women the decorative part to reflect the social status via their dresses and appearance (Craik, 1993).

The postmodern construction of personal identity through clothing is more common among the youth, famous actors, members of racial or ethnic minorities, members of groups and subcultures, sexually differentiated people willing to be considered different from the mainstream. For these reasons there was a division in men's fashion (Crane, 2000).

From the 13th to the 17th century, laws were passed regulating the cost of clothing and allow clothes depending on occupation and social class. It was an attempt of the aristocrats to keep their diversity in clothing and appearance of their socioeconomic class. As it was not possible to eliminate the fashion and consumerism of the emerging bourgeoisie they merely formalized the formation of a new dress code called "town fashions". (Craik, 1993). There is a clear separation of fashion in male and female. The female one requires constant change and innovation, imposed by the capitalist system of production and fashion with the excuse of the supposed obsession of women with elegance.

After 1960, menswear was revived and this is explained from the change in power relations at the contact between genders and change in the participation rate of women at work. Men changed their dress codes and incorporated narcissistic and superficial elements, trying to highlight the different personalities. Perhaps the garment that concluded the need of more young people to diversify and their desire to escape the pressures of the industry of men's fashion, was a humble pair of blue jeans, which was worn with a few variations and is still worn today (Entwistle, 2000). The change in characteristics of masculinity that turned men into objects in front of the female gaze imposed a change of men's fashion and design and gave way to a superficial and light appearance. This can be explained by the change of position and character. Men ceased to be the sole actors in the socio-economic power struggle, not always work in the factory or office while many work from home, others are students, and unfortunately more and more are unemployed. These changes in living conditions influence the dress code. However, there remains a diversity of gender status in costume institution (Craik, 1993).

\subsection{Construction of femininity}

\subsubsection{The Battle for the Trousers}

Since 1850, trends of women's independence emerged in the U.S., a manifestation of the fact is that they wore trousers, shocking the moralists. Since 1920, pants for women began to be tolerated in sports and some limited activities such as cycling and horse riding (Sawyer, 1987). In 1949, Richard Curle (1949) unleashed a damning indictment of women who revolt against traditional forms of femininity, calling them "sour spinsters". Earlier, in 1939, the fashion designer Elizabeth Hames argued that women were not yet ready to wear trousers at work. It took a world war to remove their corsets; will need another one to accept the trousers. As trousers symbolized male power, women who wore them where accused as unfeminine. Many movie stars like Greta Garbo, Marlene Dietrich and Katharine Hepburn had worn trousers in their movies, but they have been protected by the glamour of Hollywood and their trousers added an aura of mystery and exoticism (Arnold, 2001).

The fashion designers Coco Chanel and Madeleine Vionnet, since 1920, had suggested a soft and baggy trouser for dinner, but few women dared to wear it until 1940. Feminists, in 1970, looked at fashion as a trap for women, rejecting the traditional female dresses. Although the famous burning of bras, perhaps literally did not exist, even as a slogan, gave rise to a discussion of the view that femininity was a social construction justifying the interests of a patriarchal society (Breward \& Evans, 2005). In 1966 the famous fashion designer Yves Saint Laurence modified the male tuxedo to a female line, and it quickly became a chic expression for women who wanted to appear different. Even couture fell to the attacks and the secular feminist movement and put pants on fashion collections (Craik, 1993).

In 1984 Susan Brownmiller criticized her friends who returned to women's dresses, but also justified it by saying that perhaps it is unreasonable to ask women to leave the basic expression of their diversity from their husbands (Rodnitzky, 1999). Although in 1980s, women had not achieved full equality, there was significant progress and the fashion was a powerful tool for the reversal of traditional gender roles. Women could accept or reject the "conventional" feminine clothes without feeling guilty or rebellious and cheating (Walter, 1998). Since 1980 women have been able to wear trousers in most places without being criticized (Arnold, 2001). Different is the case of women who used too much of their femininity. They are suspected of trying to attract other women rather than to attract men. Many men feel threatened by the provocative use of female sexual power and either avoid them or treat them as a joke (Curle, 1949). 


\subsection{The role of Haute couture}

In the 1990's Haute couture was revived with a strong female character overly adorned with fancy dresses. Chief representatives of this trend are John Galliano's collections for the fashion houses Givenchy and Christian Dior and Alexander McQueen's for the fashion house of Givenchy. Their designs brought back romance, were marked as statuary and reconstructed the female identity of the late 20th century (Arnold, 2001).

\section{Dressing Movements}

The Macaroni were aristocrats who tried to distinguish themselves from the growing middle class with too quirky and weird clothes but the style was quickly discredited and refused (Craik, 1993). The Dandies are the movement introduced by Beau Brummel in London, a socially ambitious man, who tried to join the higher social circles. It was continued by Beerbohm and George de Maurier. With simple, plain clothes he tried to create the new aristocrat style. He wore starched white linen shirt with cravat and black pants, black vest and tight waisted wool coat and breeches. Everything fit perfect, was clean and crisp, and he was proud for the cleanliness. He wore soft yellow gloves and used a black walking stick with ebony handle. He was the forerunner of the modern business suit and tie (Entwistle, 2000). The movement of Mods and Teddy Boys consciously tried to reverse the values and assumptions deliberately challenged the prevailing dress code. Since 1970, the subversive style was overtaken by the decadent style of the hippies and the psychedelic unisex stars of rock, like Jimi Hendrix and the Rolling Stones (Arnold, 2001).

\subsection{Unisex and androgynous style}

Hippies in the 1960's and later the Ravers (1985 - 1995) are the protagonists of the movement that tried to conceal gender differences showing a masquerade of equality for all, obscuring the identification of sex. Despite the promise of equality unisex garment was essentially of masculine style. The basic flaw in this fashion is that the concealment of diversity with a veil is not a fair measure (Arnold, 2001). Denial of the existence of a different sexuality and even different shades of it equals to the overstressing of diversity. Both strategies aim to eventually remove individual rights (Schor, 1987). On the other side, the androgynous style seeks to unite the male and the female body in one, leading to a return to a primordial cosmic unity, which would alleviate the confusion of gender roles and the stress resulting from it. This style requires a thin, youthful and energetic body with a boyish figure and refers to adolescence. Therefore it is problematic because it requires a masculine frame and thin body, thus excluding the vast majority of men and women from it. This style is an imitation of the aristocratic identity, albeit somewhat milder due to the uncertainty of youth. Eventually the two styles emphasize the differences between the sexes.

\section{Conclusion}

Garments are items made by people and with the clear distinction in male and female show the socially constructed nature of gender differences. They have functional character, but also make statements about social class, economic status, attitudes and even the desire to comply with social norms or vary from them. Usually they are used unconsciously as a code for someone to show himself/herself to others or to declare the group that he/she belongs to and thus their sex and their sexual tint. Fashion, because of the close association with the formation of the body, mediates the negotiation of different identities, sometimes with provocation. The inherent contradiction of fashion stems from the reflection on the representation of the body in the declaration of gender identity. Fashion may indicate social frivolity but it is sociologically important because it is a result of a lengthy process and has great influence in the collective determination of society.

\section{References}

Arnold, R. (2001). Fashion, Desire and Anxiety. New York: I.B.Tauris \& Co

Bahl, V., (2005). Shifting Boundaries of "Nativity" and "Modernity" in South Asian Women's Clothes. Dialectical Anthropology, 29, 85 121.

Barnard, M. (1996). Fashion as Communication. London: Routledge.

Breward, C. \& Evans, C. (2005). Fashion and modernity. New York: Berg Publishers.

Condor, S. (1987). Newsletter of the British Psychology Society Social Section.

Cox, J., \& Dittmar, H. (1995). The Functions of Clothes and Clothing (Dis)Satisfaction: A Gender Analysis Among British Students, 
Journal of Consumer Policy, 18, 237 - 265.

Craik, J. (1993). The face of fashion. New York: Routledge

Crane, D. (2000). Fashion and its Social Agendas: Class, Gender, and Identity in Clothing. Chicago: University of Chicago Press.

Curle, R. (1949). Women, An Analytical Study. London:Watts \& Co.

Davis, F. (1988). Clothing, fashion and the dialectic of identity. In: Maines, D., \& Couch, J. (Eds.). Communication and social structure. Springfield, USA: Charles \& Thomas.

Davis, F. (1989). Of Maids' Uniforms and Blue Jeans: The Drama of Status Ambivalences in Clothing and Fashion. Qualitative Sociology, 12, $337-354$.

Davis, F. (1992). Fashion, Culture and Identity. Chicago: University of Chicago Press.

DeLong, M., Salusso-Deonier, C. \& Larntz, K. (1983). Use of Perceptions of Female Dress as an Indicator of Role Definition. Home Economics Research Journal, 4, 327 - 336.

Dodd, C., Clarke, I., Baron, S., \& Houston, V. (1998). Looking the part: Identity, meaning and culture in clothing purchasing Theoretical considerations. Journal of Fashion Marketing and Management, 4, $41-48$.

Entwistle, J. (2000). The Fashioned Body: Fashion, Dress and Modern Social Theory. Cambridge: Polity.

Flügel, J. (1930). The Psychology of Clothes. London: Hogarth.

Giles, H., \& William, C. (1975). Communication Length as a Function of Dress Style and Social Status. Perceptual and Motor Skills, 40 , $961-62$.

Holman, H. (1981). Product use as communication source. In: Enis, B., \& Roering, K. (Eds.). Review of marketing. Chicago: American Marketing Association.

Hughes, J. (2004). 'Zivil Ist Allemal Schadlich' Clothing in German - Language Culture of the 1920s. Neophilologus, 8, 429 - 445.

Kawamura, Y. (2005). Fashion-ology: An Introduction to Fashion Studies. Oxford: Berg.

Lloyd, B., \& Duveen, G. (1993). Gender and education. Hemel Hempstead: Harvester Wheatsheaf.

Lurie, A. (1981). The language of clothes. London: Heinemann.

Mayer, R., \& Belk, R. (1985). Fashion and impression formation among children. In Solomon M. (Ed.). The psychology of fashion. Lexington : Lexington Books.

Rodnitzky, J. (1999). Feminist Phoenix: the rise and fall of a feminist counterculture. London: Greenwood Publishing Group

Sawyer, C. (1987). Men in Skirts and Women in Trousers, from Achilles to Victoria Grant: One Explanation of a Comedic Paradox. The Journal of Popular Culture, 21, 1- 18.

Schor, N. (1987). Dreaming Dissymetry: Barthes, Foucault, \& Sexual Difference. In Jardine, A. \& Smith, P. (Eds). Men in Feminism, London: Methuen.

Solomon, M., \& Douglas, S. (1987). Diversity in Product Symbolism: The Case of Female Executive Clothing. Psychology \& Marketing, 4, $189-212$

Steele, V. (1989). Men and Women: Dressing the Part. Washington: Smithsonian Institution Press.

Tseelon, E. (1989). Communicating via clothes. Unpublished paper. Department of

Experimental Psychology, University of Oxford.

Walter, N. (1998). The New Feminism. London: Little, Brown \& Company 